Gál Marianna ${ }^{1 \odot}$

\title{
A Független Államok Közösségének létrejötte - a három államfői találkozó, különös tekintettel Ukrajnára
}

\author{
The Establishment of the Commonwealth of \\ Independent States - The Three Meetings of the \\ Heads of State, with Particular Reference to Ukraine
}

\begin{abstract}
Absztrakt
A Szovjetunió felbomlása és a Független Államok Közösségének (FÁK, Közösség) megalakulása - amely a balti államokon kívül valamennyi volt tagköztársaságot magába foglalt - gyökeresen új helyzetet teremtett a térségben. Az események alakulásához nagymértékben hozzájárultak az Ukrajnában végbemenő folyamatok, különösen az 1991. december 1-jén megrendezett referendum eredményei. A tanulmány ezzel összefüggésben vizsgálja a Közösség történetének első három államföi találkozóját, mégpedig a belavezsai, az alma-atai, illetve minszki találkozókat. Végül bemutatjuk a FÁK ukrán külpolitikában betöltött szerepét.
\end{abstract}

Kulcsszavak: Független Államok Közössége, ukrán külpolitika, posztszovjet térség, FÁK államföi találkozók

\begin{abstract}
The break-up of the Soviet Union and the creation of the Commonwealth of Independent States, which included all the former member republics except the Baltic States, created a radically new situation in the region. The processes in Ukraine, in particular the results of the referendum held on 1 December 1991, have greatly contributed to the events. In this context, the study examines the first three meetings of the Heads
\end{abstract}


of State in the history of the Community, namely the Belavezha, the Alma-Ata and the Minsk meetings. Finally, we present the role of the CIS in Ukrainian foreign policy.

Keywords: Commonwealth of Independent States, Ukrainian foreign policy, post-soviet region, meetings of CIS Heads of State

\section{Bevezetés}

„Belavezsai bölények”, „Belavezsa Robin Hoodjai”, a „Szovjetunió sírásói” - mindössze néhány jellemző fogalom a Független Államok Közösségét alapító, a Szovjetunió megszünését is kimondó dokumentumot kézjegyeivel ellátó három - Leonyid Kravcsuk ukrán, Sztanyiszláv Suskevics belorusz és Borisz Jelcin orosz - államfőről, amelyet Kravcsuk elnök visszaemlékezésében olvashatunk. ${ }^{2}$ Feltehetően ennél sokkal több is akad a korabeli sajtó hasábjain, amelyek közül a legizgalmasabbakat maga az első ukrán elnök is feljegyezte. Ez a néhány jellemző is mutatja, hogy egyesek számára árulókat, míg másoknak hősöket testesítették meg a belavezsai konszenzus résztvevői. A FÁK-hoz a balti államokon kívül rövidesen valamennyi posztszovjet tagköztársaság is csatlakozott az Alma-Atában megrendezett államfői találkozó keretében. Ezt követte a biztonságpolitikai formát öltött minszki találkozó, ahol a részt vevő tagállamok a Szovjetunió felbomlásával összefüggő kérdések rendezésére fókuszáltak.

A kutatás során használt és hivatkozott irodalomban dominálnak az ukrán és orosz források. Fontos kiemelni, hogy a memoárok, illetve interjúk feldolgozása során - az úgynevezett emlékháborúkkal összhangban - számos ellentétes információval találkozunk a vadászházban történt eseményekre vonatkozóan, ami megnehezítette az objektív mérlegelést.

\section{A belavezsai konszenzus}

A belavezsai konszenzus megnevezést a dokumentum aláírásának helyszínéról kapta, az 1991. december 7-8. között a belaruszi Viszkuliban található - Lengyelországhoz közeli - Belavezsai Puscsában (vagy Belavezsszkaja Puscsában) tartott találkozóról. $A z$, hogy mi is történt az itt található vadászházban, a jelenlévők visszaemlékezéseiből ismerhető meg részletesen. Kravcsuk memoárjából tudhatjuk, hogy a mintegy improvizációnak nevezett találkozót nem rögzítették pontosan előre, a soron következő megbeszélések egyike volt. ${ }^{3}$ Szervezése azonban már feltételezhetően az Ukrajnában történt események - vagyis közvetlenül a december 1-jén megtartott referendum és Leonyid Kravcsuk elnökké választása - után elkezdődhetett, amelynek eredményei már elvben megtagadták a Gorbacsov-féle uniós szerződés aláirását Ukrajna

Леонід Кравчук: Маємо те, що маємо: спогади іроздуми. Київ, 2002. 135.

Кравчук (2002) i. m. 128. 
számára. ${ }^{4}$ A népszavazás változásokat eredményezett, és nagyrészt meghatározta a Szovjetunió további sorsát. Ritkán említett az a közel sem elhanyagolható tény, hogy a referendumot követően a világ nemzetei sorra elismerték Ukrajna függetlenné válását: 1991. december 2. és december 8. között 10 állam, december 31-ig 37, köztük Oroszország még december 5 -én. ${ }^{5}$ Ebböl a szempontból nem túlzás azt állítani, hogy Ukrajna kulcsa lett a Szovjetunió felosztásának.

Az ukrán delegáció késő este érkezett a lengyel határtól három kilométerre található vadászházba, amely a hruscsovi időkben a legmagasabb szintű külföldi delegációk számára fenntartott fogadások helyszíne volt. „December 7-én telefonált a belorusz parlament elnöke és felajánlotta, látogassam meg. Ismertette, hogy Minszkbe már megérkezett az Oroszországi Föderáció elnöke... Suskevics hangsúlyozta, Jelcin ajánlja hármunk számára, hogy találkozzunk és megbeszéljük (az előzetes tervek szerint) az új Szövetségi szerződés kilátásait"6 - írta Leonyid Kravcsuk, aki felkészülten várta kollégája telefonhívását. Kravcsuk az ország függetlenségét alátámasztó referendum eredményét figyelembe véve készült az integráció új szakaszához, ami azt jelentette, kész volt tárgyalásokat folytatni és aláírni egy olyan szövetségi szerződést, amely elősegítette volna az ország Szovjetunióból történő kiválását, és amely szerkezetét tekintve az európai közösségi rendszerhez közelített.

A belavezsai találkozó kutatása során számos feltételezéssel találkozhatunk arra vonatkozóan, hogy az orosz fél valóban kész szerződésköteggel érkezett-e Viszkuliba? Ezt a kérdést a jelenlévők ugyan maximálisan cáfolták: „Nem, nem volt ilyen dokumentum" - jegyezte meg Burbulisz az 1990-es évek. A mítoszok megsemmisítése címü projekt kapcsán készített interjújában, hozzátéve „de volt többhónapos munka ezt megelőzően...". Mind ő, mind az orosz delegáció másik tagja, Szergej Sahraj azt állították, hogy Borisz Jelcin csupán azért repült Minszkbe, hogy megvitassa az alacsonyabb árú olaj- és gázellátási feltételeket, mivel Belarusz gazdasága akkor nagyon nehéz helyzetben volt. ${ }^{8}$ Jelcin beszédet mondott a belarusz parlamentben, majd mintegy kikapcsolódásként a Breszt közeli vadászházba utaztak a delegáció tagjai. Hasonlóképpen idézte ezt fel visszaemlékezésében a belarusz elnök is, aki javaslatot tett arra vonatkozóan, hogy még Kravcsukot is hívják meg, és háromoldalú kommünikét írjanak alá. A találkozó házigazdája egyébként nem készített előterjesztést, várakozó álláspontjával az orosz és ukrán elnökök által kialakított együttes megoldás elfogadására készült fel. Az orosz delegáció kiindulópontja az volt, hogy mivel a köztársaságok deklarálták függetlenségüket, a helyzet új perspektívát kínált az országok további kapcsolatainak megszervezésére. Szergej Sahraj számos interjúban határozottan állította, hogy a Szovjetunió már Belavezsa előtt „halott" volt, és Viszkuliban lényegében - akár

4 Az 1991. december 1-jén megtartott referendum eredménye szerint 32 milliós fős lakosság $90 \%$-a igennel voksolt a következő kérdésre: „Ön támogatja Ukrajna Függetlenségi Nyilatkozatát?” Forrás: ЦДАВО України. - Ф.1. - Оп.28. Спр.144. - Арк.6.

5 Ukrajna függetlenségének elismeréséről lásd részletesebben országok szerint: Визнання України як незалежної держави. Online: https://old.uinp.gov.ua/publication/viznannya-ukraini-yak-nezalezhnoi-derzhavi

Кравчук (2002) i. m. 129.

Геннадий Бурбулис - в проекте „90-е. Разрушение мифов". 19 января 2016 г.

Юрий Воронин: Стреноженная Россия. Политико-економический портрет ельцинизма. Москва, Республика, 2003. 69. 
az orvosok - „csak a halálának tényét rögzítették...". ${ }^{9}$ Sahraj szerint - aki egyébként jogi végezettséggel bírt - az ügy lényege abban rejlett, hogy a Szovjetuniót 1922-ben Oroszország, Ukrajna, Belarusz és a Kaukázusontúli Szocialista Föderatív Szovjet Köztársaság (KSZFSZK) hozta létre. Miután azonban a KSZFSZK már nem létezett, ezen országoknak történelmi jogukban állt deklarálni szövetségük felszámolását. ${ }^{10}$ A jelcini csapat felfogása azért meghatározó, mert jogi alapot is adtak a dokumentum születéséhez. Ebből a szempontból Ukrajna jelenlétére lényegében a sahraji legitimáció nézőpont igazolása miatt lehetett szükség. A találkozó napirendjére került témát az orosz fél kezdeményezte, ami azért fontos, mert jellemzően Kravcsuk és Suskevics szükség szerint visszautalhatott az oroszokra. Így mindketten nagy örömmel támogatták a jelcini verziót a sahraji jogi megalapozás szerint. Jelcinnek feltett szándékában állt, hogy Minszkben felszámolja a Szovjetuniót. Utazásának célját azonban még a legszűkebb környezete elöl is eltitkolta. „Csak azt mondta, hogy vele kell repülni Minszkbe a jövőbeli lehetőségek megvitatása, az együttműködés erősítése, valamint Oroszország, Ukrajna és Belarusz politikájának összehangolása miatt"11 - emlékszik vissza Jegor Gajdar orosz miniszterelnök, ami arra utal, nem csak Belarusz gazdasági problémáiról szeretett volna Jelcin tárgyalásokat folytatni. Jurij Voronyin professzor, aki az Oroszországi Szovjet Föderatív Szocialista Köztársaság (OSZFSZK) Legfelsőbb Tanácsának elnökhelyetteseként jól ismerte a jelcini csapat tagjait - vagyis Sahrajt, Gajdart és Gennagyij Burbuliszt -, akik a belavezsai találkozó után azon tanakodtak, hogy közülük ki járult hozzá leginkább a Szovjetunió felszámolásáról szóló dokumentum megszületéséhez. Sahraj azzal dicsekedett, hogy ő javasolta és készítette elő a formulát, Gajdar pedig azzal, hogy ő jegyezte le a szöveget. Burbulisz szintén büszkélkedett a találkozó eredményével: „Belavezsa volt a legboldogabb nap az életemben."12

A dokumentum aláirására másnap, vagyis a december 8-án a délutáni órákban ünnepi légkörben megrendezett sajtókonferencia keretében került sor. A preambulumból és 14 cikkelyből álló alapdokumentum - „Megállapodás a Független Államok Közösségének létrehozásáról” - kimondta, hogy a „Szovjetunió megszűnik”, és helyette kinyilvánítják a FÁK létrehozását, amely nyitott más független államok csatlakozására. A Megállapodás szólt a kölcsönösen előnyös együttműködés fejlesztéséről a politika, a gazdaság, a kultúra, a tudomány, a kereskedelem, az egészség stb. területeken koordinációs intézményeken keresztül. Ezenkívül a konszenzus több tekintetben érinti a biztonságpolitika szféráját: elismerik a határok sérthetetlenségét, és tiszteletben tartják egymás területi integritását; törekednek a béke és biztonság fenntartásának stabilitásában, tiszteletben tartják egymás törekvését a semleges állam státusának és nukleárismentes övezet eléréséhez. Ez különösen aktuális volt Ukrajna számára, aki már a szuverenitási deklarációjában atommentes politikát hirdetett; a Közösség tagjai közös parancsnokság alatt fenntartják a katonai-stratégiai teret, ideértve a nukleáris fegyverek egységes irányítását, amelynek eljárását a későbbiekben külön megállapodás szabályozza majd.

Сергей Шахрай: „После этих событий Ельцин стал более замкнутым, более злым и мстительным.” Ю. М. Воронин. Беловежское предательство. Lásd www.za-nauku.ru/index.php?option=com_content\&task=view\&id=3619\&ltemid=33 Воронин (2003) і. m. 69.

Егор Гайдар: Дни поражений и побед. Москва, 1996. 61.

Воронин (2003) i. m. 70. 
A Közösség alapítói egy kiegészítő dokumentumot is elfogadtak - az „Államfők Nyilatkozatát” -, amelyben konstatálták, hogy „az új uniós szerződésről szóló tárgyalások elakadtak, a köztársaságok Szovjetunióból való kiválásának és az önálló államok megalakulásának objektív folyamata valóra vált", mert „a központ szűklátókörü politikája mély gazdasági és politikai válsághoz vezetett, a termelés összeomlásához, az életszínvonal katasztrofális csökkenéséhez gyakorlatilag a társadalom minden rétegében".13

A szerződés ünnepélyes aláirásának napján, a sorrendje tekintetében sem elhanyagolható néhány momentumra szükségszerü reflektálnunk, mégpedig elsőként a vadászházból történt telefonhívásokra. A Jekatyerinburgban nyílt Jelcin Központ archívumában elérhető a titkosított telefonbeszélgetések alól feloldott 28 perces beszélgetés George Bush és Borisz Jelcin között, akit első körben értesítettek a találkozó eredményeiről. ${ }^{14} \mathrm{~A}$ telefonbeszélgetés szövegéből kiderül, hogy már Jevgenyij Saposnyikov marsallal és Nurszultán Nazarbajev kazah elnökkel is kapcsolatba léptek és tájékoztatták a megbeszélés eredményeiröl. Nazarbajev elnök ígéretet tett arra vonatkozóan, hogy a vadászházba utazik a dokumentum aláirásához, azonban ez nem történt meg. ${ }^{15}$ Gorbacsov informálása csak ezek után következett, akit Sztanyiszláv Suskevics hívott fel. A belorusz elnök memoárjában viszont szilárdan állítja - ahogy egyébként Kravcsuk is megjegyezte -, hogy Bush és Gorbacsov irányába azonos időben történtek a telefonhívások, viszont technikai okokból ez utóbbit később érték el: „Mire engem kapcsoltak Gorbacsovhoz, a másik telefonon már kapcsolták Busht. Miközben hallottam, hogy mi történik ott, magyaráztam Gorbacsovnak, hogy aláírtunk egy dokumentumot, amelynek ez és ez a lényege. Gorbacsov kioktató, mentori tónusban azt mondta: Maguk el tudják képzelni, miként reagál erre a nemzetközi közvélemény? Tisztelt Mihail Szergejevics, minden rendben van ebben a tekintetben. Jelcin már elmagyarázta Bushnak a történteket, és Ő üdvözölte. Ettől kezdve Gorbacsov magázni kezdett engem." ${ }^{16}$ Ezzel szinte ellentétes módon derült ki a Bush-Jelcin telefonbeszélgetés szövegéből, hogy Gorbacsov még nem tudott semmiröl.17

Az események másik résztvevője, Petr Kravcsenko belarusz külügyminiszter szerint egyáltalán nem valamiféle improvizáció volt a belavezsai találkozó. Jeleit annak, hogy valami fontos dolog fog történni Belarusz területén már néhány héttel azelőtt érzékelte, hogy maguk az események bekövetkeztek volna. Ezt azzal magyarázta, hogy november közepén elöször Eduárd Sevarnadze, a Szovjetunió utolsó külügyminisztere, majd egy amerikai médiamágnás december eleji látogatását halasztották el azzal az indokkal, hogy december 7-én Kravcsuk és Jelcin érkeznek Belaruszba. ${ }^{18}$ Az orosz delegáció fogadását követően, úton a vadászházba kollégájával ${ }^{19}$ folytatott beszélgetését

\footnotetext{
Заява Глав держав республіки Білорусь, РРФСР, України.

14 Рассекречены стенограммы телефонных разговоров первых лиц государства с американским президентом.; Svetlana Savranskaya - Thomas Blanton: The Last Superpower Summits: Gorbachev, Reagan, and Bush. Conversations that ended the cold war. Budapest - New York, 2016. 974

15 Витольд Фокин. „В гостях у Дмитрия Гордона”. 2/6 (2016).

16 Станислав Шушкевич: Моя жизнь, крушение и воскрешение СССР. Москва, 2012. 191.

17 Savranskaya-Blanton (2016) i. m. 975.

18 Петр Кравченко. Беларусь на распутье, или правда о Беловежском соглашение. Записки дипломата и политика. Москва, Время, 2006. 148.

19 Az orosz külügyminiszterrel, Andrej Kozirjevvel folytatott beszélgetést úton a vadászházba.
} 
így tolmácsolta memoárjában: „[E]lőször tudtam meg, Viszkuliban nem egyszerü találkozóra kerül sor." Az orosz külügyminiszter szerint ugyanis „[t]ervben van egy dokumentum létrehozása és aláírása, amely azonosíthatja és meghatározza a szemünk előtt zajló állami folyamatokat". ${ }^{20}$ Miután Kravcsenko megjegyezte - a dokumentum előkésztése miatt -, „nehéz dolgunk lesz, ami nem kevesebb egy hétig tarthat”, orosz kollégája válaszul csak mosolygott.

A második fontos mozzanat a Bush-Jelcin telefonbeszélgetést rögzítő dokumentumon feltüntetett idő, ami szerint ellenőrizhető, az a reggeli órákban történt. Gorbacsovnak módjában állt volna a helyszínre utazni, hiszen a hivatalos aláírásra csak délután került sor, noha megakadályozni aligha tudta volna azt. A belavezsai konszenzus résztvevőiben mindemellett munkálkodott a félelem. Noha Kravcsuk többször ismételte "Gorbacsov az erő módszerét nem alkalmazza", ${ }^{21}$ erre utal, hogy a helyszínt helikopterekkel biztosították menekülés esetén. Gorbacsov azonban nem készült beavatkozásra. Az ukrán delegáció az esti órákban visszatért Kijevbe. Másnapra Mihail Szergejevics ugyan Moszkvába rendelte a konszenzus résztvevőit, az elutasításra talált. December 10-én pedig az ukrán Legfelsőbb Tanács napirendi pontja között szerepelt a dokumentum ratifikációjának kérdése.

\section{Az utódállamok csatlakozása}

A bomlási-csatlakozási folyamatokhoz rövidesen valamennyi volt szovjet tagköztársaság is társult. 1991. december 21-én megtartott második államfői találkozón a korabeli kazah fővárosban, Alma-Atában, a balti hármas és Grúzia kivitelével (aki csak később, 1993-ban csatlakozott) további nyolc tagköztársaság aláírta a FÁK-alapelvekkel osztozó deklarációt négy pontban. ${ }^{22}$

Az első, a demokratikus jogállam kialakítására irányuló törekvés, amely keretén belül a közöttük lévő kapcsolatok az államaik önállóságának és szuverén egyenlőségének kölcsönös elismerésén és tiszteletben tartásán alapulva fejlődnek. Leszögezték azt is, hogy alapvetőnek tekintik az önrendelkezés, az egyenjogúság és az egymás belügyeibe be nem avatkozás elvét. Elítélik az erő alkalmazását és a vele történő fenyegetést, a gazdasági és bármely más nyomásgyakorlási módszert, az esetlegesen felmerülő viták esetében azok békés rendezését létesítik előnyben. Tiszteletben tartják az emberi jogokat, ideértve a nemzeti kisebbségek jogait, illetve a nemzetközi jog minden más általánosan elismert elvét és normatíváját.

A második pontban elismerik és tiszteletben tartják a létező határok megváltoztathatatlanságát, egymás területi integritását.

A deklaráció harmadik pontjában - amely a béke és biztonság szempontjából kiemelt helyet foglal el - rögzítették, hogy a meglévő mély történelmi gyökerü baráti viszonyokat, jószomszédságot és kölcsönösen elönyös együttműködést tekintik a népeik alapvető érdekének, ezért azok erősítése a céljuk.

\footnotetext{
Кравченко (2006) i. m. 151.

Воронин (2003) i. m. 71.

22 Azerbajdzsán, Örményország, Kazahsztán, Kirgizisztán, Moldova, Tádzsikisztán, Türkmenisztán, Üzbegisztán csatlakozik a FÁK-hoz. Алма-Атинская Декларация: http://cis.minsk.by/reestr/ru/index.html\#reestr/view/text?doc=4
} 
Végül, a negyedik pontban kifejezésre került, tisztában vannak azzal, hogy felelősséggel tartoznak országaikban a béke és a nemzetiségek közötti egyetértés, illetve a világ biztonságának a megörzéséért.

A FÁK-tagállamok a fentebb vázolt alapelveik és céljaik megvalósítása érdekében szervezeti intézkedéseket hoztak Alma-Atában. Ilyen volt:

- a tagállamok közötti együttmüködést biztosító koordinációs szervek létrehozása, amelyek nem nemzetek feletti jelleggel müködnek, hanem a tagállamok megállapodásai alapján;

- a nemzetközi stratégiai stabilitás és biztonság fenntartása érdekében a katonai-stratégiai erők közös parancsnoksága és a nukleáris fegyverzet feletti egységes ellenőrzés továbbra is fennmarad. Emellett a felek tiszteletben tartják egymás törekvését a nukleárisfegyver-mentes és (vagy) semleges állam státuszának elérésére; ${ }^{23}$

- megerősítik elkötelezettségüket a közös gazdasági térség kialakításában és fejlesztésében;

- a FÁK tagállamai garantálják a saját alkotmányuk és törvényeik rendelkezéseivel összhangban a volt Szovjetunió által vállalt egyezményekből és megállapodásokból rájuk háruló nemzetközi kötelezettségeket. ${ }^{24}$

Látható tehát, hogy a Szovjetunió megszűnésének hivatalossá tétele körül hangzatos alapelvek és célok fogalmazódtak meg, amelyet egyben bizonytalanság is jellemez. A volt integráló erőkből egyedül a katonai-stratégiai fegyveres erők közös parancsnoksága és a nukleáris fegyverzet feletti egységes ellenőrzést próbálták továbbra is fenntartani a biztonságpolitika szempontjából. Nem volt azonban egységes álláspont a hogyan továbbról, hiszen a Szovjetunió felbontását szentesítő orosz elnök és a körülötte lévő elit a Független Államok Közösségében az orosz irányítású szovjet hadsereg folytatásaként a FÄK Egységes Fegyveres Erőit képzelte el Saposnyikov repülőmarsall vezetésével. E nézettel a tábornoki és tiszti kar és a védelmi ipar vezetése is egyetértett. Technikai okok is szóltak a fegyveres erők egysége mellett, ráadásul az osztozkodás azért is problémás volt, mert számos FÁK-államban fegyveres konfliktus dúlt. Az alma-atai találkozó viszont nem adott egyértelmű választ arra vonatkozóan, milyen is legyen a volt Fegyveres Erők jellege: egyesített vagy egységes, milyen legyen az összetétele, kinek az irányítása alatt müködik majd? Ezekre a kérdésekre a minszki FÁK államfői találkozó választ keresett.

\section{A minszki találkozó}

A Független Államok Közössége államfői találkozójára a FÁK székhelyén, Minszkben került sor 1991. december 30-án. A biztonságpolitikai tematikájú csúcstalálkozón részt vevő valamennyi tagköztársaság vezetői olyan kérdésekben próbáltak

23 Ezzel összefüggésben egy jegyzőkönyv is született, amelyben Jevgenyij Saposnyikov marsallt bízzák meg a fegyveres erök reformja kérdésének megoldására. Lásd Протокол наради Глав Незалежних Держав; Зібрання чинних міжнародних договорів України від 1990-1990 р., № 1, 319. Online: https://zakon.rada.gov.ua/laws/main/b94

24 Алма-Атинская Декларация. 
eredményeket elérni, amelyekben az előző értekezletek viszonylatában a bizonytalanság jellemzett.

A minszki találkozón a Szovjetunió felszámolás alatt álló Védelmi Minisztériuma helyébe lépő FÁK Egyesített Fegyveres Erők Főparancsnokságának létrehozásáról döntöttek, miközben fenntartották a részes államok saját haderő realizálására vonatkozó jogokat, a felbomlás pillanatában területükön állomásozott egységek alapján. Ukrajna, Azerbajdzsán és Moldova saját nemzeti hadsereg létrehozását is bejelentették, elvetve ezzel az egységességre irányuló törekvések lehetőségét. Az Egyesített Főparancsnokság egyébként a széttartó tagállami érdekek miatt csak néhány évig, a Szovjetunió fegyveres erőinek a köztársaságok közötti végleges felosztásáig, 1993 decemberéig múködöttt. ${ }^{25}$ A részes tagállamok elismerték a stratégiai erők közös parancsnokságának szükségességét, valamint a volt Szovjetunió fegyveres erőinek nukleáris fegyverek és egyéb tömegpusztító fegyverek egységes ellenörzésének fenntartását. İgy a stratégiai erők kivételt képeztek és közös parancsnokság alatt maradtak az Államfők Tanácsa irányításával. ${ }^{26} \mathrm{~A}$ minszki találkozón megállapodtak abban is, hogy ezen stratégiai erők közös irányítása alatt csak azok a katonai formációk fognak szerepelni, amelyeket az egyes államok külön jegyzőkönyvben előterjesztenek. A későbbi események azonban arra engednek következtetni, hogy a katonai dokumentumok csomagját aláiró szerződő feleknek nem volt egységes elképzelésük sem arra vonatkozóan, mi tartozik a stratégiai erők fogalmához, sem pedig arról, milyen státusszal is rendelkezzenek. Itt elsősorban a Fekete-tengeri Flotta felosztásának rendezésére kell gondolnunk, amely 1992 januárjától hosszú időn keresztül az orosz-ukrán kétoldalú dialógus szimptomatikus ügyét jelentette, amely nemcsak annak fokozatos romlásához vezetett, de nagymértékben kihatott a két ország kapcsolatára is.

Biztonságpolitikát érintő kérdéseken túl a tagállamok kölcsönösen elismerték a Szovjetunió tulajdonának méltányos részesedésesére vonatkozó jogokat. A vagyon elosztásának realizálásához pedig egy kormányközi bizottság létrehozásáról is döntöttek. ${ }^{27}$ Mint ismeretes, Ukrajna részesedése 16,37\% volt az 1992. június 6 -án elfogadott megállapodás szerint. ${ }^{28}$

Minszkben számos kiegészítő dokumentumot is elfogadtak, amelyek az örmény földrengés utáni segítségnyújtásról, a csernobili katasztrófa következményeinek kiküszöböléséről, a Kaszpi-tenger halászati erőforrásainak védelméről szóltak.

Minszkben összességében kilenc államfői és hat kormányfői megállapodás született.

\section{A FÁK-koncepció meghatározása az ukrán külpolitikában}
A Szovjetunió felbomlása gyökeresen új helyzetet teremtett a térségben. A poszt- szovjet köztársaságok hosszú idő után kerülhettek közvetlen - Moszkva közbeiktatása nélküli - kapcsolatba a világ többi részével. Az önálló ukrán külpolitikai koncepció

\footnotetext{
Объединенные Вооруженные Силы Содружества Независимых Государств (ОВС СНГ).

Зібрання чинних міжнародних договорів України: Офіційне видання - Том 1: 1990-1991. Київ, 2001.

Зібрання чинних міжнародних договорів України від 1990-1990 р., № 1, 417.
}
28 Угода про розподіл всієї власності колишнього Союзу РСР за кордоном. 
formálódását a szuverenitási deklarációban rögzített három alapelv - az atommentesség, tömbönkívüliség és semlegesség - határozta meg, amely elé a későbbi FÁK-tagság sem állított akadályt, ugyanis a belavezsai dokumentum 6. cikkelyében a szerződő felek leszögezték, "tiszteletben tartják egymás törekvését atomfegyvermentes övezetek és semleges államok státuszának elérésére". ${ }^{29}$ A kezdeti ukrán elképzelés legfőbb sajátossága egy ideiglenes jellegű elszakadási stratégia az előző élettérből. ${ }^{30}$ A koncepció azért nevezhető ideiglenesnek, mert egy átmeneti időszak - vagyis az alárendelt szereptől a teljes szuverenitás eléréséig tartó folyamat - problémáit volt hivatott megoldani. A függetlenség feletti öröm csillapodása után a gazdasági válság mélységének lassú felismerése, a válságból kivezető út megtalálásának kilátástalansága egy idő után módosította a politikusok önbizalomtól duzzadó magatartását. Főként a FÁK fennállásának elmúlt évtizedében a résztvevő tagállamok vezetőinek az 1990-es évek elején kialakult illúziói merültek feledésbe, miszerint az országaikban elért függetlenség még önmagukban nem jelentenek felvirágzást, és az emberek jólétét sem vonják maguk után. Lassan döbbentek rá arra, hogy bár Ukrajna politikailag független állámmá vált, sok tekintetben ezer szállal - leginkább gazdasági szempontból - kötődik a szovjet utódállamokhoz, főként Oroszországhoz. Világossá vált, hogy az önállóság valójában nem jelenthet elszigetelődést, mert helyzetükből adódóan önállóan nem sikerülhet a felzárkózást a fejlődés fő útvonalára terelni. ${ }^{31}$

Miután az ukrán külpolitika központi vezérlő elve az önálló államiság kiteljesedése és a függetlenség következetes védelme köré épült, a Közösséget a „civilizált szétválás eszközeként" határozta meg. ${ }^{32} \mathrm{Az}$ új alapokra helyezett Közösség építése háttérbe helyeződött az államok önállóságának kiépítésével szemben. Ezt szemléltetik a FÁK létrehozásáról szóló szerződés ratifikációja ${ }^{33}$ során megfogalmazott fenntartások is, amikor a Legfelsőbb Tanács túlnyomó többséggel elfogadta és kiemelte a paritás elve alapján történő együttmüködést, következetesen elutasította annak szupranacionális irányba történő fejlesztését, hangsúlyozta a területi integritást, a meglévő határok sérthetetlenségére irányuló törekvéseket a FÁK külső határaival szemben. ${ }^{34}$

Az 1990-es évek második felében a pragmatikusság szerint aktivizálta a térségben fenntartott kapcsolatait, különös tekintettel az egyetlen Oroszország részvétele nélküli csoporttal, a GUAM - Szervezet a Demokráciáért és Gazdasági Fejlödésért képződménnyel. Kijev ezzel az álláspontjával azon tagállamok közé tartozott, akik ad hoc alapon, az együttmüködés számára előnyös szegmensére koncentráltak, a reintegráció, illetve integráció erőltetése nélkül, föként konzultatív fórumként használták a Közösséget. A teljes mértékben önkétességi alapon történő csatlakozást az egyes egyezményekhez, illetve struktúrákhoz elsősorban a saját érdekek figyelembevétele határozta, illetve határozza meg, ami az együttes cselekvést blokkolja.

A Független Államok Közösségére irányult kapcsolatendszert az 1993. július 2-án Ukrajna külpolitikájának fö irányvonalai elnevezésü dokumentum nyomatékosította.

\footnotetext{
2 Угода про створення СНД.

30 Póti László: Ukrajna kül- és biztonságpoltikája, 1990-2000. Budapest, 2001. 10.

31 Kemény László: A Szovjetunióból a 21. század Oroszországig. Budapest, 2017. 194.

32 Георгий Касьянов: Україна 1991-2007: очерки новейшей истории. Київ, 2008. 117.

33 A 354 jelenlévő képviselőből 288 támogatta a szerződés ratifikációját. Стенограма пленарного засідання. Засідання сорок п'яте. Сесійний зал Верховної Ради України. 10 грудня 1991 року. 16 година.

34 Про ратифікацію Угоди про створення СНД.
} 
A dokumentum több passzusa is azt a törekvést tükrözi, hogy ebben a rendszerben a kapcsolatok a lehető leglazább formákat öltsék. A dokumentumban deklarált négy prioritásból kettő - az első, illetve harmadik tétele - a posztszovjet térségre irányult:

- az első tétel a kétoldalú kapcsolatokat jelölte, amelyben Oroszország különleges helyet foglalt el, és amellyel Ukrajna "kiemelt partnerségre törekszik";

- a harmadik tétel pedig egyenesen a FÁK-at jelöli meg, amelyre mint a Szovjetunió szétesését menedzselő multilaterális fórumként tekint, ahol a kapcsolatok fejlesztését elsősorban bilaterális módon építik. ${ }^{35}$

Hasonlóképpen tükrözte a FÁK-hoz füződő nézetet az ukrán diplomácia lépése, miszerint az 1993. január 22-én elfogadott - a Közösség céljait és alapelveit, a tagországok kötelezettségeit és jogait tartalmazó - FÁK Alapokmány aláírását elutasította, de jure nem minősült tejes jogú FÁK-tagállamnak. Az Alapokmány II. fejezete 7. cikkelye ugyanis három kategóriába differenciálta a közösségi tagságot:

- Az első az alapító államok kategóriája, amelyhez azok a tagállamok tartoznak, amelyek az Alapokmány elfogadásáig aláírták és ratifikálták a FÁK Alapító Okiratát a hozzátartozó Jegyzőkönyvvel. Ide Ukrajna és Türkmenisztán tartoznak.

- A második, a tagállamok kategóriája, amelyhez azok az alapító államok tartoznak, amelyek az Alapokmányt ratifikálták elfogadásától számított egy éven belül. Ide Belaruszt, Oroszországot, Örményországot, Kazahsztánt, Kirgizisztánt, Moldovát, Tádzsikisztánt és Üzbegisztánt sorolhatjuk.

- A harmadik, a tagok kategóriája, amelyhez a FÁK-alapelvekkel és -célokkal osztozó államok tartozhatnak azáltal, hogy csatlakoznak az Alapokmányhoz valamennyi résztvevő jóváhagyásával. Ilyen volt Grúzia tagsága 1994. április 19. - 2009. július 18. között.

Ukrajna tehát a fentebb részletezett kategóriák alapján az „alapokmányon kívüli” alapító államok közé tartozik. Más szempontból viszont tekintettel arra, hogy egyrészt a Közösség építése az Alapokmányban foglaltak szerint történik, részben Ukrajna is elfogadja bizonyos normáit, annak ellenére, hogy aláírta volna, másrészt összehasonlításra jó alapot kínálhat azokkal a tagállamokkal szemben, amelyek kötelezettségeket vállaltak a dokumentum aláirása által.

\section{6. Összegzés}

1991. december 8-án az addigra már felbomlás elörehaladott állapotába jutott Szovjetunió három tagköztársaságának vezetői egy belarusz vadászházban döntöttek annak megszüntetéséről, amelyet egy lazább, konföderáció jellegű szövetséggel kívántak felváltani a történelmileg megteremtett kapcsolataik megörzéséhez. A Független Államok Közösségéhez rövidesen valamennyi posztszovjet tagállam is csatlakozott.

Ami külpolitikai orientáció másik két prioritását illeti, a regionális együttműködés a második pontként fogalmazódott meg, míg negyedikként az univerzális dimenzió, ami az ENSZ-ben és annak szakosított szerveiben történő részvételt jelölte. Про Основні напрями зовнішньої політики України: https://zakon.rada.gov.ua/laws/show/3360-12 
Az események ilyen jellegü alakulásához központi szerepet tulajdoníthatunk Ukrajna független állami státuszának, aki, noha bábáskodott alapító tagállamként a civilizált szétválás eszközeként, a lazább FÁK-tagság mellett döntött.

A vizsgálat a FÁK története szempontjából lényeges három államfői találkozóra fókuszált, amelynek során nemcsak lefektették a Közösség jogi alapjait, de meghatározták a céljait és alapelveit, müködésének alapjait annak érdekében, hogy megfelelő színteret biztosítsanak a felmerült problémák rendezéséhez, különös tekintettel az utódlást érintő kérdésekre. A szovjet éra öröksége azonban rendkívül összetett feladat elé állította a FÁK-tagállamokat. Nyugati kutatók már az 1990-es évek elején több lehetséges forgatókönyvröl beszéltek a posztszovjet államok kapcsolatát illetően, amelyek mindegyike Ukrajna és Oroszország kapcsolatának romlását vetítette elő. Mások egyenesen a FÁK legrövidebb időn belüli szétesését prognosztizálták, amely feltételezésük szerint a Szovjetunió utódlása kérdéseinek rendezésével következik be, ugyanis ezzel nem marad közös ügyük, ami összetarthatja a Közösséget.

\section{Felhasznált irodalom}

Воронин, Юрий: Стреноженная Россия. Политико-економический портрет ельцинизма. Москва, Республика, 2003.

Гайдар, Егор: Дни поражений и побед. Москва, 1996.

Касьянов, Георгий: Україна 1991-2007: очерки новейшей истории. Київ, 2008. Kemény László: A Szovjetunióból a 21. század Oroszországig. Budapest, 2017. Кравчук, Леонід: Маємо те, що маємо: спогади і роздуми. Київ, 2002.

МЗС України: Зібрання чинних міжнародних договорів України від 1990-1990 p., № 1.

Петр Кравченко: Беларусь на распутье, или правда о Беловежском соглашение. Записки дипломата и политика. Москва, Время, 2006.

Póti László: Ukrajna kül- és biztonságpoltikája, 1990-2000. Budapest, 2001.

Шушкевич, Станислав: Моя жизнь, крушение и воскрешение СССР. Москва, 2012. Savranskaya, Svetlana - Thomas Blanton: The Last Superpower Summits: Gorbachev, Reagan, and Bush. Conversations that ended the cold war. Budapest - New York, 2016.

\section{Levéltári forrás}

ЦДАВО України. - Ф.1. - Оп.28. - Спр.144. - Арк.6 


\section{Internetes források}

Алма-Атинская Декларация. Online: http://cis.minsk.by/reestr/ru/index.html\#reestr/view/text?doc=4

Витольд Фокин. "В гостях у Дмитрия Гордона". 2/6 (2016). Online: www.youtube. com/watch?v=aJpRICDdQT8

Геннадий Бурбулис - в проекте „90-е. Разрушение мифов”. 19 января 2016 г. Online: https://yeltsin.ru/news/gennadiy-burbulis-v-proekte-90e-razrushenie-mifov/

Заява Глав держав республіки Білорусь, РРФСР, України. Online: https://zakon. rada.gov.ua/laws/show/998_087

Объединенные Вооруженные Силы Содружества Независимых Государств (ОВС СНГ). Online: http://cis.minsk.by/reestr/ru/index.html\#reestr/view/text?doc=65

Про ратифікацію Угоди про створення СНД. Online: https://zakon.rada.gov.ua/ laws/show/1958-12

Про Основні напрями зовнішньої політики України. Online: https://zakon.rada. gov.ua/laws/show/3360-12

Протокол наради Глав Незалежних Держав. Online: https://zakon.rada.gov.ua/ laws/show/997_190\#Text

Рассекречены стенограммы телефонных разговоров первых лиц государства с американским президентом. Online: www.ural.kp.ru/daily/26469/3338973/

Сергей Шахрай: „После этих событий Ельцин стал более замкнутым, более злым и мстительным." Online: www.forbes.ru/ekonomika/lyudi/75584-posle-etih-sobytii-eltsin-stal-bolee-zamknutym-bolee-zlym-i-bolee-mstitelnym

Стенограма пленарного засідання. Засідання сорок п'яте. Сесійний зал Верховної Ради України. 10 грудня 1991 року. 16 година. Online: https://iportal.rada.gov. ua/meeting/stenogr/show/4641.html

Угода про створення СНД. Online: https://zakon.rada.gov.ua/laws/show/997_077 Угода Глав держав СНД про власність колишнього СРСР за кордоном. Online: https://zakon.rada.gov.ua/laws/show/997_236\#Text 